\title{
DeCreased CD4+CD152+ T CELl SubSET AND Its Correlation WITH THE LEVEL OF ANTITHYROID ANTIBODIES IN CHILDREN WITH Chronic Autoimmune Thyroiditis
}

\author{
A. M. Kucharska1, E. Gorska², M. Wasik², B. Pyrzak ${ }^{1}$ \\ ${ }^{1}$ Department of Pediatrics and Endocrinology and ${ }^{2}$ Department of Laboratory Diagnostics and Clinical Immunology of the Developmental \\ Age, Warsaw Medical University, Warsaw, Poland
}

\begin{abstract}
Objective: Cytotoxic T lymphocyte antigen-4 (CTLA4 ) is one of the basic antigens involved in immune responses regulation associated with autoimmune thyroid diseases. The aim of the study was to evaluate whether the surface expression of CTLA-4(CD152) on $\mathrm{T}$ cells is correlated with laboratory autoimmune markers in children with Hashimoto's disease.

Material and methods: Blood samples were obtained from 45 children with Hashimoto's thyroiditis of the mean age $14.8 \pm 2.35$ years, and from 55 healthy agematched children, free of allergic, immune and hematological disorders, and with a normal thyroid function. The anti-thyroid antibodies were measured with Microparticle Enzyme Immunoassay (AxSYM AntiTg, AxSYM Anti-TPO). The T cell phenotype was evaluated flow cytometery, with the use of monoclonal antibodies combination: CD4- FITC/ CD28 -PC5/ CD152 -PE and CD8 -FITC/ CD28 -PC5/ CD152 PE

Results: The percentage of $\mathrm{T}$ cells with CD152 expression was significantly decreased in children with Hashimoto's thyroiditis compared with healthy controls $(\mathrm{P}<0.001)$. A significant negative correlation was found between the level of anti-thyroglobulin antibodies and the percentage of CD4+CD152+ T cells $(r=-$ $0.34 ; \mathrm{P}<0.05)$. Anti-thyroperoxidase antibodies did not correlate with CD152 expression.

Conclusions: In children with Hashimoto's thyroiditis, the number of CD4+CD152+ T cells is decreased and negatively correlates with the level of anti-thyroglobulin antibodies.
\end{abstract}

Key words: CTLA-4 expression, anti-thyroid antibodies, children, Hashimoto's thyroiditis

\section{INTRODUCTION}

Hashimoto's thyroiditis and Graves' disease are the two classic types of autoimmune thyroid diseases. They differ from each other in immune and clinical aspects, but their pathogenetic background is similar. Like many other autoimmune diseases, they develop as the result of coincidence of genetic susceptibility and environmental factors. According to the statistical model based on Graves' disease in Danish twins, the genetic susceptibility seems to be the most important factor in the autoimmune thyroid disease development [1]. Genes encoding cytotoxic T lymphocyte antigen-4 (CTLA-4) and human leukocyte antigens (HLA) are proposed as being the most significant susceptibility genes for these thyroid disorders [2]. The former encodes the lymphocytic antigen, which plays a key role in the regulation of the immune responses. The CTLA-4 is an important negative regulator of the T cell activation. It has a role in the key pathway of $\mathrm{T}$ cell activation together with the other $\mathrm{T}$ cell antigen, CD28. They both bind to the same ligands: B7.1 and B7.2 on the antigen presenting cells. The CD28 induces the stimulatory signal for activation and the CTLA-4 (CD152) for termination of an immune response. It is well established that the lack of CD152 causes lymphoproliferative disorders in experimental animal models $[3,4]$. In humans, CTLA-4 gene was described as being associated with many autoimmune diseases, particularly thyroid autoimmune diseases [2, 5]. The influence of CTLA-4 gene polymorphisms on the clinical course of autoimmune thyroid disorders and the association of CTLA-4 gene with anti-thyroid antibody production in patients with Graves' disease or autoimmune thyroiditis has been documented in several studies [6-9]. However, the molecular mechanisms of that association have not yet been clearly elucidated. Therefore, the aim of the present study was to investigate whether CD152 expression on the surface of $T$ cell would correlate with the level of antithyroid antibodies in young patients with Hashimoto's thyroiditis (H'T).

\section{Material And Methods}

The study was approved by the Bioethics Committee of Warsaw Medical University in Warsaw, Poland. Parents of patients signed informed consent for the participation in the study.

Blood samples were obtained from 45 children with chronic autoimmune thyroiditis and from 55 healthy children, age- and sex-matched, free of allergic, immune and hematological disorders, and with a normal thyroid function. The mean age of HT patients was $14.8 \pm 2.4$ years and that of control subjects was 14.6 \pm 2.3 years. The diagnosis of HT was based on the 
presence of anti-thyroperoxidase (anti-TPO) and antithyroglobulin antibodies (anti-Tg), and on the typical ultrasonographic appearance of the thyroid gland.

The anti-thyroid antibodies were measured with Microparticle Enzyme Immunoassay: AxSYM Anti-Tg and AxSYM Anti-TPO (Abbott Laboratories, Abbott Park, IL, USA). The positive result for anti-Tg was taken as $>34 \mathrm{IU} / \mathrm{ml}$ and for anti-TPO antibodies as $>12 \mathrm{IU} / \mathrm{ml}$. Cell preparation before cytometric analysis was described previously [10]. In brief, heparinized blood samples from HT children and healthy controls were diluted in saline three times, and centrifuged for $30 \mathrm{~min}$ by $400 \mathrm{x} g$ on Histopaque 1077-1 density gradient from SIGMA Diagnostics (St. Louis, MO, USA). The isolated peripheral blood mononuclear cells (PBMC) were incubated with monoclonal antibodies for $30 \mathrm{~min}$ at $25^{\circ} \mathrm{C}$ in darkness. Analysis was performed with the use of monoclonal antibody combination: CD4- FITC/CD28 -PC5/CD152 -PE and CD8 -FITC/CD28 -PC5/CD152 -PE obtained from Immunotech Beckman Coulter Company (Beckman Coulter Company, Paris Nord, France). After incubation samples were fixed and lysed by the reagent set Uti-Lyse (Dako Cytomation, Gdynia, Poland). The T cell phenotype was evaluated using the flow cytometer Beckman Coulter EPICS XL 4C (EPICS XL/XLMCL, version 2.0, Beckman Coulter Company, Paris Nord, France).

Results were statistically analyzed with a $t$-test, Mann-Whitney U test, and Spearman's test for correlations, as required.

\section{RESULTS}

In tricolor cytometry, a significantly decreased percentage of T cells with CD152 expression was found in the children with HT compared with healthy controls: $2.6 \pm 1.8$ and $4.5 \pm 1.5 \%$, respectively $(\mathrm{P}<0.001)$. The difference was statistically significant in both basic T cell subsets: CD4+ and CD8+ (Table 1). The percentages of CD4+CD152+ $\mathrm{T}$ cells were

Table 1. Baseline CD phenotypes of T cells in children with Hashimoto's thyroiditis and in healthy controls.

\begin{tabular}{l|cc}
\hline $\begin{array}{l}\text { T cell subset } \\
\text { (antygen) }\end{array}$ & $\begin{array}{l}\text { Contribution in peripheral } \\
\text { Blood mononuclear cells } \\
\text { (mean } \% \pm \text { SD) }\end{array}$ \\
\hline & Hashimoto's & Controls \\
\hline CD4+CD28+ & $20.6 \pm 9.6$ & $21.1 \pm 9.5$ \\
CD4+CD152+ & $1.0 \pm 0.8^{*}$ & $2.51 \pm 1.6^{*}$ \\
CD8+CD28+ & $7.9 \pm 4.9$ & $7.9 \pm 3.5$ \\
CD8+CD152+ & $1.2 \pm 1.6^{*}$ & $2.5 \pm 2.0^{*}$ \\
CD4+ & $23.7 \pm 10.1$ & $23.9 \pm 9.6$ \\
CD8+ & $16.6 \pm 8.3$ & $16.9 \pm 5.9$ \\
CD28+ & $32.2 \pm 14.2$ & $33.2 \pm 12.7$ \\
CD152+ & $2.6 \pm 1.8^{*}$ & $4.5 \pm 1.5^{*}$ \\
\hline
\end{tabular}

$* \mathrm{P}<0.05$ for the difference between the two groups.

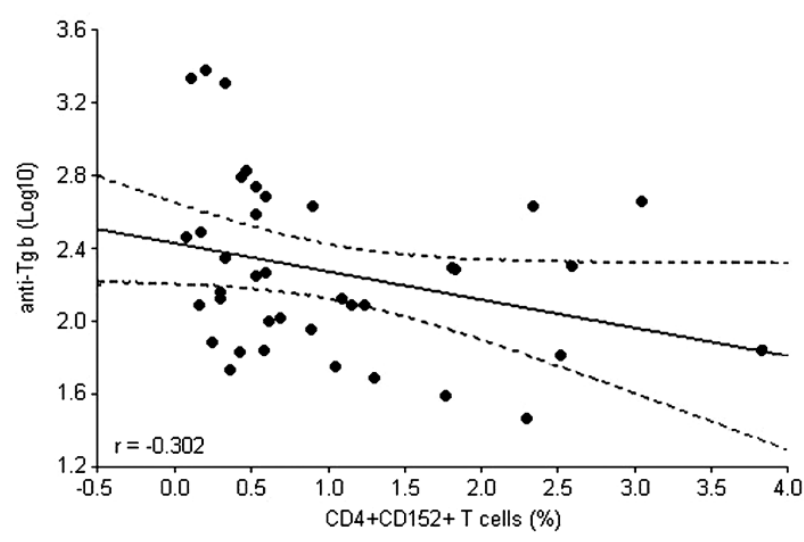

Fig. 1. Correlation between anti-thyroglobulin antibodies and the number of CD4+CD152+ T cells.

$1.0 \pm 0.8$ in the HT children vs. $2.5 \pm 1.6 \%$ in controls $(\mathrm{P}<0.0001)$, and those of CD8+CD152+ T cells were $1.2 \pm 1.6$ vs. $2.5 \pm 2.0 \%$, respectively $(\mathrm{P}<0.0004)$. The total number of CD4+ and CD8+ T cells was similar in the HT patients and controls. The percentage of $\mathrm{T}$ cells expressing the CD28 antigen also was comparable in the HT patients and controls (Table 1).

In the HT children, the only significant correlation found was that between the level of anti-Tg antibodies and the number of CD4+CD152+ $\mathrm{T}$ cells ( $\mathrm{r}=-0.3$; $\mathrm{P}<0.05$ ) (Fig. 1). The other antigens examined did not correlate with either anti-Tg or anti-TPO antibodies. However, the anti-Tg and anti-TPO antibodies positively correlated with each other $(\mathrm{r}=0.34 ; \mathrm{P}<0.04)$.

\section{DisCUSSION}

The CD152 (CTLA-4) is a key negative regulator of Tcell activation. Previous studies based on the association between the CTLA-4 gene polymorphisms and Graves's disease and Hashimoto's thyroiditis showed that this antigen is involved in the pathogenesis of autoimmune thyroid diseases. Nevertheless, the functional effect of particular polymorphisms has not yet been elucidated. Anjos et al [11] suggested that the impairment of CTLA-4 function is due to decreased surface expression of CD152 on T cells. They explained it with alterations in the signal peptide of CTLA-4, leading to impaired processing to the cell surface. Our previous observation that the percentage of $\mathrm{T}$ cells with the surface expression of CD152 was significantly lower in children with Hashimoto's thyroiditis than in healthy controls is in agreement with the above outlined results [12]. In the present study we found that in patients with a lower amount of CD152+ T cells, the level of anti-thyroglobulin antibodies was statistically greater. The explanation of this finding seems to be a logical consequence of CTLA-4 function. The expression of CD152+ on T cells is a key factor for the termination of an immune response. Thus, a decreased number of CD152+ T cells can be responsible for a continuous activation of autoreactive $\mathrm{T}$ cells and for the development of autoimmune processes. This is in agreement with Anjos et al [11], who reported a decreased amount of CTLA-4 on the T cell surface, 
which promotes $\mathrm{T}$ lymphocyte proliferation leading to autoimmune disease.

Laboratory markers of autoimmune thyroiditis are the anti-thyroid autoantibodies. In our patients, only did anti-thyroglobulin antibodies correlate with decreased expression of CD152 and anti-thyroperoxidase antibodies did not. Some studies of the natural course of Hashimoto's thyroiditis in children have shown that anti-thyroglobulin antibodies can appear earlier and reach higher levels than anti-thyroperoxidase antibodies. The preponderance of anti-thyroglobulin antibodies at early stages of autoimmune thyroiditis in children has been documented in several papers $[13,14]$. The best human models for the investigation of the natural development of autoimmune thyroiditis are the populations who initiate the mandatory iodination. According to these data, several years after the start of iodination anti-thyroglobulin antibodies rise as the first marker of autoimmune thyroiditis $[15,16]$. The hypothesis that thyroglobulin is a thyroid antigen, easily available to the immune system, which can initiate an autoimmune response remains still attractive [17-19]. It is known that iodination of the thyroglobulin particle alters its immunogenicity and exposes cryptic epitopes, which may break the peripheral tolerance and initiate an autoimmune process [19]. Anti-Tg antibodies are normally found in human serum, but they are referred to as natural autoantibodies, are polyspecific, and have different affinity for epitopes than anti-Tg antibodies from patients with Hashimoto's thyroiditis [20]. In the present study, our patients' antiTg antibodies correlated with decreasing expression of CD152, especially on CD4+ T cell. This T cell subset is important in humoral responses and antibodies production. It is known that the level of anti-thyroid antibodies is not constant in patients with autoimmune thyroiditis and varies during the disease development. The correlation between the level of antibodies and CD152 expression found in our patients may suggest that CD152 expression on CD4+ might be involved in alterations of antibodies in the course of disease. This observation requires further supportive explorations and a follow-up of the examined patients. We conclude that in children with Hashimoto's thyroiditis the number of $\mathrm{T}$ cell positive for CD152 is decreased compared with healthy children. The number of CD4+CD152+ T cells negatively correlates with the level of anti-thyroglobulin antibodies.

Conflicts of interests: The authors declare no conflicts of interest in relation to this article.

\section{REFERENCES}

1. Brix TH, Kyvik KO, Hegedius L. Evidence for a major role of heredity in Graves' disease: a population -based study of two Danish twin cohorts. J Clin Endocrinol Metab 2001; 86: 930-4.

2. Tomer Y, Davies TF. Searching for the autoimmune thyroid disease susceptibility genes: from gene mapping to gene function. Endocr Rev 2003; 24(5): 694-717.

3. Tivol EA, Borriello F, Schwieitzer AN, Lynch WP, Bluestone JA, Sharpe AH. Loss of CTLA-4 leads to massive lymphoproliferation and fatal multiorgan tissue destruction, revealing a critical negative regulatory role of CTLA-4. Immunity 1995; 3(5): 541-7.
4. Waterhouse P, Penninger JM, Timms E, Wakeham A, Shahinian A, Lee KP, Thompson CB, Griesser H, Mak TW. Lymphoproliferative disorders with early lethality in mice deficient in CTLA-4. Science 1995, 270: 985-8.

5. Kavvoura FK, Akamizu T, Awata T, Ban Y, Chistiakov DA, Frydecka I, Ghaderi A, Gough SC, Hiromatsu Y, Ploski R, Wang P-W, Ban Y, Bednarczuk T, Chistiakova EI, Chojm M, Heward JM, Hiratani H, Juo S-HH, Karabon L, Katayama S, Kurihara S, Liu R-T, Miyake I, Omrani GHR, Pawlak E, Taniyama M, Tozaki T, Ioannidis JP. CTLA-4 gene polymorphism and autoimmune thyroid disease: A meta-analysis. J Clin Endocrinol Metab 2007; 92(8): 162-70.

6. Tomer Y, Greenberg DA, Barbesino G, Conception E, Davies TF. CTLA-4 and not CD28 is a susceptibility gene for thyroid autoantibody production. J Clin Endocrinol Metab 2001; 86: 1687-93.

7. Zaletel K, Krhin B, Gaberscek S, Pirnat E, Hojker S. The influence of the exon-1 polymorphism of the cytotoxic $\mathrm{T}$ lymphocyte antigen 4 gene on thyroid antibody production in patients with newly diagnosed Graves' disease. Thyroid 2002; 12:373-6.

8. Zaletel K, Krhin B, Gaberscek S, Hojker S. Thyroid autoantibody production is influenced by exon-1 an promoter CTLA-4 polymorphisms in patients with Hashimoto's thyroiditis. Int J Immunogenet 2006; 33: 87-91.

9. Bossowski A, Stasiak-Barmuta A, Urban M. Relationship between CTLA-4 and CD28 Molecule Expression on T lymphocytes and stimulating and blocking autoantibodies to the TSH-receptor in children with Graves' disease. Horm Res 2005; 64: 189-97.

10. Kucharska AM, Gorska E, Wasik M, Pyrzak B, Demkow U. Expression of CD152 (CTLA-4) in children with autoimmune thyroiditis and $+49 \mathrm{~A} / \mathrm{G}$ polymorphism of exon 1 of the CTLA-4 gene. J Pharmacol Physiol 2009; 60 Suppl 5: 77-80.

11. Anjos S, Nguyen A, Ounissi-Benkalha H, Tessler MC, Polychronakos C. A common autoimmunity predisposing signal peptide variant of the cytotoxic T-lymphocyte antigen 4 results in inefficient glycosylation of the susceptibility allele. J Biol Chem 2002; 277: 46478-86.

12. Kucharska AM, Gorska E, Wasik M, Demkow U. Altered expression of $\mathrm{T}$ lymphocyte surface markers in children with chronic autoimmune thyroiditis. J Pharmacol Physiol 2008; 59 Suppl 6: 375-82.

13. Radetti G, Gottardi E, Bona G, Corrias A, Salardi S, Loche S. The natural history of euthyroid Hashimoto's thyroiditis in children. J Pediatr 2006; 149: 827-32.

14. de Vries L, Bulvik S, Phillip M. Chronic autoimmune thyroiditis in children and adolescents: at presentation and during long-term follow-up. Arch Dis Child 2009; 94: 33-7.

15. Mazziotti G, Premawardhana LDKE, Parkes AB, Adams H, Smyth PPA, Smyth DF, Kaluaraci WN, Wijeyaratne CN, Jayasinghe A, de Silva DGH, Lazarus JH. Evolution of thyroid autoimmunity during iodine prophylaxis - the Sri Lankan experience. Eur J Endocrinol 2003, 149: 103-10.

16. Premawardhana LDKE, Parkes AB, Smyth PPA, Smyth DF, Wijeyaratne CN, Jayasinghe A, da Silva DGH, Lazarus JH. Increased prevalence of thyroglobulin antibodies in Sri Lankan schoolgirls- is iodine the cause? Eur J Endocrinol 2000; 143: 185-8.

17. Duthoit C, Estienne V, Giraud A, Durand- Gorde J-M, Rasmussen AK, Feldt-Rasmussen U, Carayon P, Ruf J. Hydrogen peroxide-induced production of a $40 \mathrm{kDa}$ immunoreactive thyroglobulin fragment in human thyroid cells: the onset of thyroid autoimmunity? Biochem J 2001; 360: 557-62.

18. Lindberg B, Svensson J, Ericsson UB, Nilsson P, Svenonius E, Ivarsson SA. Comparison of some different methods for analysis of thyroid autoantibodies: Importance of thyroglobulin autoantibodies. Thyroid 2001; 11: 265-9. 
19. Gentile F, Conte M, Formisano S. Thyroglobulin as an autoantigen: What can we learn about immunopathogenicity from the correlation of antigenic properties with protein structure? Immunology 2004; 112: 13-25.

20. Besler HS, Burek CL, Hoffman WH, Rose NR. Autoantigenic determinants on human thyroglobulin. II. Determinants recognized by autoantibodies from patients with chronic autoimmune thyroiditis compared to autoantibodies from healthy subjects. Clin Immunol Immunopathol 1990; 54: 76-86.
Address for correspondence:

Anna M. Kucharska

Klinika Pediatrii i Endokrynologii

Warszawski Uniwersytet Medyczny

24 Marszalkowska St.

00-756 Warszawa

Poland

Phone: +48225227307

Fax: +48 226214155

E-mail: anna.kucharska@litewska.edu.pl 